\title{
Additív gyártással készülő egyéni implantátumok lézeres mikrohegesztésének vizsgálata
}

\section{Examination of Laser Microwelded Joints of Additively Manufactured Individual Implants}

\author{
Kónya János, ${ }^{1}$ Kulcsár Klaudia ${ }^{2}$ \\ ${ }^{1}$ Dent-Art-Technik Kft. Győr, Magyarország, labor@dentarttechnik.hu \\ ${ }^{2}$ Dent-Art-Technik Kft. Györ, Magyarország, kulcsar.klaudia@dentarttechnik.hu
}

\begin{abstract}
Digital product processing and the utilization of novel, tissue-friendly materials allow the use of fixed dentures for patients. Its basis is a titanium plate fixed to the cortical bone surface at given screw positions. A digital dental cast is created from the existing bone surface, and modelling and necessary statistical analyses are carried out in a virtual environment. Safety of the welded joint is evaluated with mechanical methods. When designing the fixing points, an idealized denture is used that was previously designed for the patient. The number and position of pillar elements used for screw fixation of the denture are determined by the complex geometry of the denture itself, and the location, direction, and articulating position of existing teeth. The additively manufactured implant and the machined pillar sleeves are joined with laser-welding at given nesting positions. Homogeneity of the metallic material structure at the welded joint zone of the product is examined with micro-CT. Due to this implementation method, surgical time decreases together with complication rates and post-operative problems
\end{abstract}

Keywords: additive manufacturing, implant, laser micro welding, titanium, $3 D$ printings.

\section{Összefoglalás}

A digitális termékfeldolgozás és az új, korszerü, szövetbarát anyagok alkalmazása lehetővé teszik a páciensek számára a rögzített fogmű használatát. Alapja a csavarozási pontokon a kortikális csontfelszínhez rögzített titánlemez. Digitálisan képeztünk lenyomatot a csontfelszínről, virtuális térben modelleztük és végeztük el a szükséges statikai analíziseket. A hegesztett kötés biztonságát mechanikai módszerrel ellenőriztük. A rögzítési pontok tervezésénél felhasználjuk a páciens számára virtuálisan megalkotott, idealizált fogművet. Ezen fogmủ komplex geometriája és a terven szereplő fogak pozíciója, iránya, valamint artikulációs helyzete határozza meg a fogpótlás csavaros rögzítésére szolgáló pillérelemek számát, illetve elhelyezkedését. Az additív módon megvalósított tervet a rajta elhelyezett illesztőgyürűknél forgácsolással létrehozott pillérperselyeket lézeres hegesztéssel rögzítettük. A mikro-CT segítségével elemeztük a hegesztési varrat mellett a gyártmány fémszerkezetének homogenitását. A megvalósítási módszernek köszönhetően csökken a műtéti idő, mellette a szövődmények lehetősége, valamint a posztoperatív probléma.

Kulcsszavak: additív gyártás, implantátum, lézeres mikrohegesztés, titán, 3D nyomtatás.

\section{Bevezetés}

A titán és ötvözetei az ipari, valamint az egészségügyi alkalmazások egyik legjobb műszaki fémének tekinthetők. A Ti-6Al-4V ötvözetet kiváló szakítószilárdsága, élettartam-szilárdsága és korrózióállósága miatt főként repülőgépiparban és sebészeti implantátumok gyártásánál alkalmazzák [1]. A titán, kereskedelmileg tiszta titán vagy titánötvözetek hegesztése szükséges a repülőgépiparban, valamint az orvostechnikai eszközök gyártásánál. A titán és ötvözetei előnyösek sebészeti implantátumok és protézisek gyártására, mert kiváló korrózióállóságot, mechanikai tu- 
lajdonságokat és biokompatibilitást biztosítanak [2]. A lézeres hegesztést sokféle orvosi termék, például pészméker, defibrillátor, katéter és ortopédiai implantátumok gyártására használják [3]. Beültethető implantátumok esetén biokompatibilis fémeket és ötvözeteket, például titánt, nitinolt, kobaltalapú ötvözeteket, rozsdamentes acélt, platinát és nióbiumot alkalmaznak. A titán egyedülálló anyag, mely figyelmet igényel a feldolgozás minden területén, különösen a hegesztés során [4]. A titán hegesztéstechnológiája bonyolult, mivel $550{ }^{\circ} \mathrm{C}$ feletti hőmérsékleten, de különösen olvadt állapotban reakcióképes a légköri gázokkal, például oxigénnel és nitrogénnel. A hegesztés előtt és alatt a kötő- és töltőanyagok nem megfelelő előkészítése és tisztítása, a hegesztési zóna rossz védelme vagy a védőgázban lévő szennyeződések szennyezettséget okozhatnak [5-7].

Számos rögzítésre szolgáló folyamatot alkalmaznak a titán esetében, mint például a volfrámelektródás védőgázos ívhegesztés, lézersugaras hegesztés és keményforrasztás [2]. Jelenleg három különböző adalékanyag-használati technikát vizsgálnak fémek esetében: a közvetlen lézeres hegesztést [8-10], az elektronsugaras felrakóhegesztést [11] és a fémfelhordást (SMD). A nagy vákuumtér költséges létrehozásával szemben jobb megoldást nyújt az Ar-atmoszféra [15]. A titán ömlesztőhegesztése főleg védőgázzal és nagy energiájú sugárnyalábbal történik. Az elektronsugaras hegesztés a költségei ellenére kiválóan alkalmas a titánpor szemcséinek összekötésére, mivel vákuum van a kamrán belül, ahol a folyamatot végrehajtják, és az a forró fémet megvédi a szennyeződéstől [16, 17]. A titánötvözet hegesztési folyamata gyakran a volfrámelektródás védőgázos ívhegesztés a viszonylag könnyebb alkalmazhatóság és jobb gazdaságosság miatt. A mágneses ívlengetés és az impulzusos áram népszerübb, mivel ezeket a technikákat a meglévő hegesztőberendezések kisebb módosításával tényleges ipari szituációkra alkalmazhatják [18].

Számos vizsgálat foglalkozott a tiszta titán és a titánötvözetek hegesztési mikroszerkezetének és mechanikai tulajdonságainak a változásával a levegő okozta szennyezés hatására [19]. Az additív gyártással előállított Ti-6Al-4V ötvözet esetében kétféle hegesztést hasonlítottak össze: az egyik a $\mathrm{Nd}$ :YAG lézerrel végzett lézersugaras hegesztés, a másik a volfrámelektródás, védőgázos ívhegesztés [20]. Grade2-es ötvözetlen titánon végeztek vizsgálatokat és arra a következtetésre jutottak, hogy a hegesztési zóna elszíneződése korrelál a védőgázhiánnyal, a varratfém oxigén- és nitro- géntartalmával, valamint a hőhatásövezet mechanikai tulajdonságaival [19]. Azonban ez a korreláció a hegesztési felület színén és a varratfém szennyezőin kívül más változók függvénye is. Kimutatták, hogy a hegesztési futtatási szín csak a felületi szennyeződést jelezte [19]. Az argon védőgázban lévő oxigénszennyeződés hatását vizsgálták a varratfém mikrostruktúrájára és tulajdonságaira vékony lemezek lézeres hegesztése során. A kísérleti eredményeket főként optikai és pásztázó elektronmikroszkóppal kapták. A mechanikai vizsgálatokkal kapcsolatot mutattak ki a hegesztési felület színe, a varratstruktúra és a mechanikai tulajdonságok (szilárdság, duktilitás, keménység) között [19].

\section{A precíziós öntéssel gyártott subperi- ostealis implantátum}

Az újragondolás eredményeként létrejött implantátumszerkezetet hagyományos öntési eljárással hoztuk létre, melynek megvalósítása komoly akadályokba ütközött. A fémszerkezet homogenitása, a kerámia beágyazó forma kopásából, eróziójából, valamint a kerámiából leváló részecskék implantátumszerkezetbe való beágyazódási problémái megnehezítik a szükséges manuális utómunkálatokat. Az öntvény egyetlen szerkezeti elemet tartalmazott, a felfekvőfelület perforált lemeze és a rögzítőcsonkok egybe voltak öntve (1. ábra). A csavarozási pontok kialakítása a párhuzamos pozicionálás után történt.

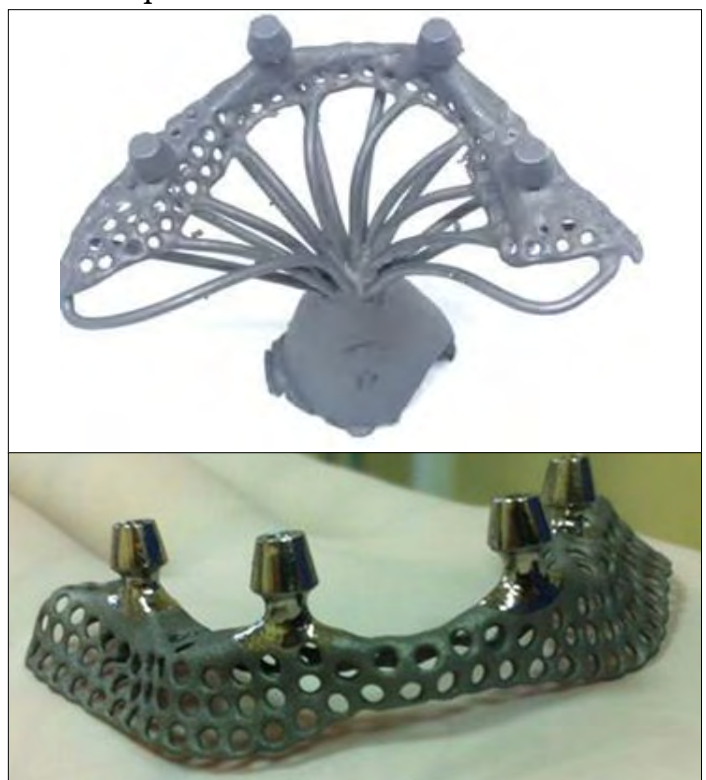

1. ábra. Egybeöntött titán fémszerkezet nyers öntvénye és a beültetésre kész implantátum 
A furatok és a menet kialakítása során a fémszerkezet homogenitását ellenőrző mikro-CT-s, roncsolásmentes anyagvizsgálatot végeztünk (2. ábra). Az eredmény szoftveres elemzése során, az esetek 80\%-át meghaladóan, az anyagszerkezetet károsan befolyásoló és a kialakítást nehezítő öntvényhibákra bukkantunk. Az első javítóintézkedésünk célja a lézeres hegesztő segítségével végzett feltárás után a belső zárványok javítása, feltöltése volt. A beavatkozás után a feltöltött anyagszerkezet mechanikai szilárdsága és megmunkálhatósága eltért az öntvény anyagszerkezetétől, ami tovább nehezítette a rögzítési pontok kialakítását.
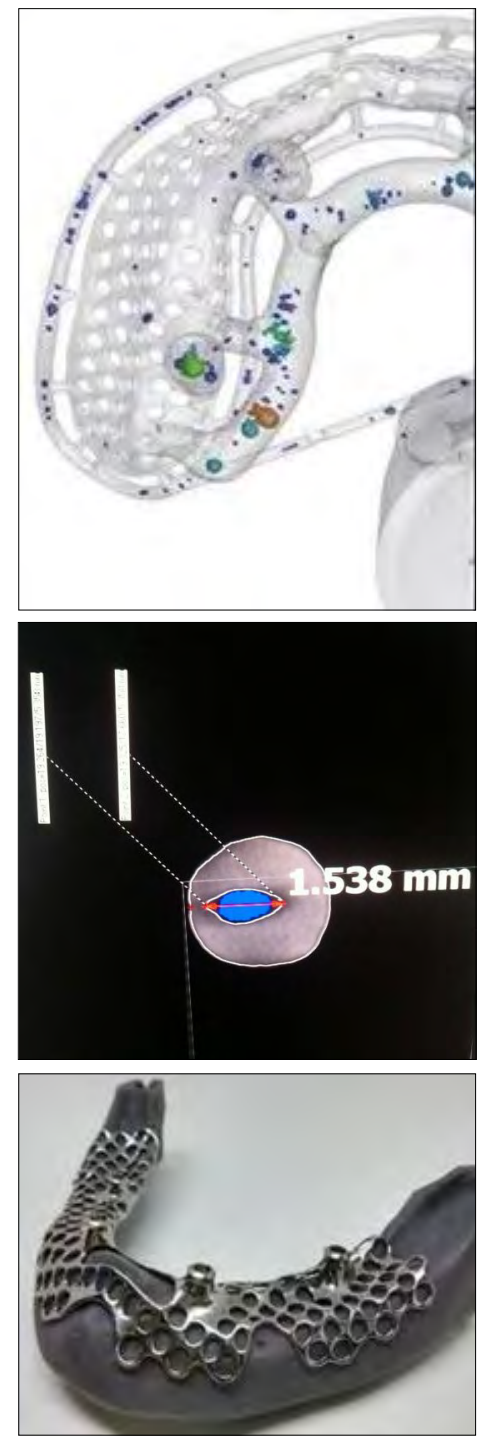

2. ábra. A mikro-CT-felvételeken feltárt folytonossági hiányok, gázzárványok láthatók

\section{Kétfázisú pillérek tervezése és vizs- gálata}

A korábbi tapasztalatok és eredmények felhasználásával egy komplex megoldást hoztunk létre, amely az öntött alapszerkezetnek és az öntéssel párhuzamosan, körszimmetrikus forgácsolással létrehozott pillérszerkezeteknek - melyek már tartalmazták a végleges rögzítési pontokat is - lézeres hegesztéssel történő egyesítését jelentette. Ez a megoldás vált be, mivel biztosította számunkra a szükséges szilárdságot és szerkezeti stabilitást. Ily módon tudtuk létrehozni, az öntvény alapszerkezethez hegesztett pillér előgyártmány precíziós megmunkálhatósága révén, a nagy felületi pontosságú illeszkedést a kapcsolódó implantátumelemek számára.

Az így kialakított, kétfázisú implantátum kapcsolódási elemeire a tapasztalatok alapján azért volt szükség, mert a beültető műtéttel a mütéti heg a varrattal zárható, és lerövidíti a gyógyulás idejét. Ekkor a rögzítő pillérek menetes perselyei záró, úgynevezett gyógyulási csavarokat kaphatnak.

A menetes perselyek további előnyei a szerelhetőség, javíthatóság és az adott felhasználási szituációhoz való pillérkialakítás variációinak sokszínűsége, ami tengelykorrekciókat, speciális elhelyezkedésű és ínyvastagságú megoldási lehetőségeket hordoz magában.

Az ily módon korábban gyártott implantátumainknak nem volt meg az alapos anyagvizsgálati és szerkezetanalitikai hátterük, amelyet a virtuális tervezés, a Cone Beam Computer Tomography (СВCT-) felvételekből kinyert információk új dimenziója és a speciális informatikai szoftverek alkalmazása tettek számunkra lehetővé. Ezáltal újragondoltuk a subperiostealis implantátumot, amelyet már a virtuális térben történt tervezés után szubsztraktív, anyagleválasztással történő 3D-s megmunkálással hoztunk létre. Mind a hálószerkezetet és a rögzítési pontokat, mind a szerelhetőséget a számítástechnika adta lehetőségekkel, valamint a korábbi tapasztalatainkkal ötvözve valósítottuk meg (3. ábra).

\section{A hálószerkezet végeselem-módszer- rel végzett analízise}

A végeselem-módszerrel végzett analízis a fizikai szerkezet virtuális modelljét kezeli, amely magában foglalja az elemeket, anyagmodelleket, peremfeltételeket és mindazon tulajdonságokat, amelyek a fizikai valóságot modellezik [30] (4. ábra). 

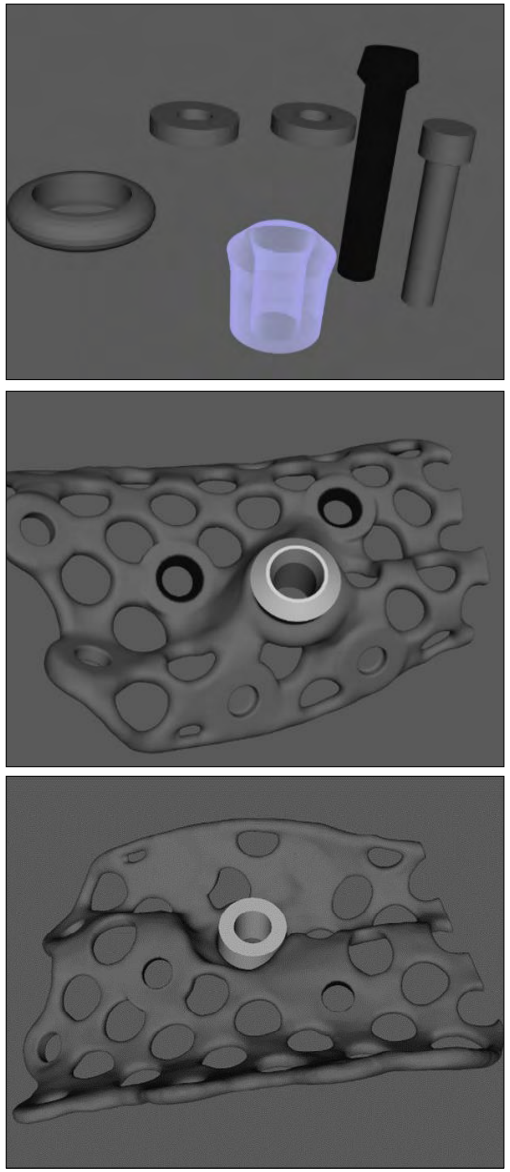

3. ábra. A tervezett pillérelemek és a hálókonstrukción történő virtuális egyesítésük

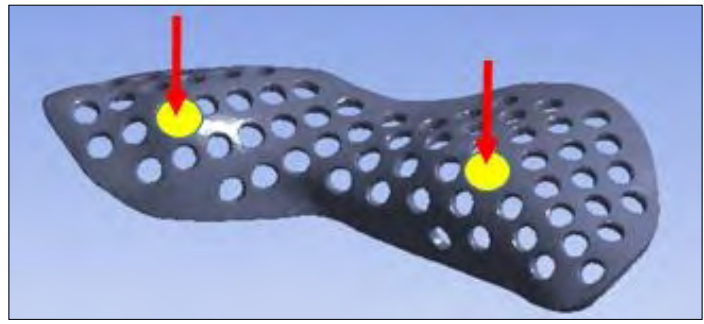

4. ábra. A pillérek elhelyezése a testmodellen

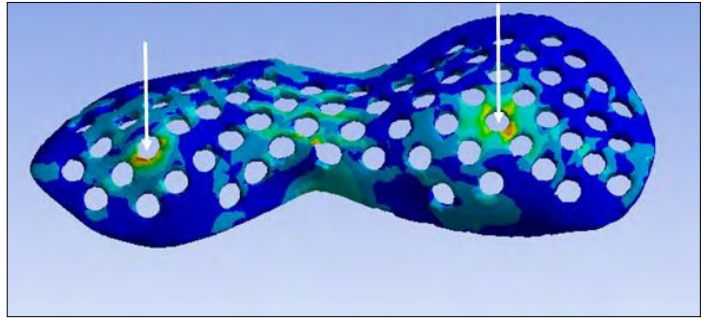

5. ábra. Az elhelyezett pillérek környezetének feszültségmezője
A végeselem-módszerrel végzett analízissel a lemez feszültségállapotát vizsgáltuk azokon a területeken, ahová lézeres mikrohegesztéssel beépítjük a menetes perselyt, melyre a felépítmény csatlakozik. Az 5. ábrán a terhelés iránya és a feszültségállapot látható. A terhelőerő megállapításánál ebben az esetben $150 \mathrm{~N}$ tengelyirányú rágóerővel és ennek horizontális komponenseivel számoltunk, figyelembe véve az átlagos csonthiányos eseteknél felmerülő, 15 mm-es interocclusalis térközt.

A véges elemek módszerével végzett vizsgálat a hálószerkezet méreteinek meghatározásában nyújtott nagy segítséget, amelyben idealizáltuk az adott terhelőerőhöz a háló kiterjesztését, perifériáit, a minimális anyagvastagságot és a perforáció átmérőjét, sűrűségét és elhelyezkedését.

\section{Hegesztett Ti-ötvözet-minták mecha- nikai vizsgálatai}

A szerkezeti elemek, mint a háló és a menetes persely anyaga titánötvözet, de míg a hálós szerkezetet additív módon, Grade 23-as titánból hoztuk létre, addig a CNC-esztergával létrehozott menetes perselyelemek húzott, Grade 5-ös titánból készültek. Korábbi gyakorlati tapasztalatunk már volt a Grade 1-es öntött és a Grade 5-ös titán Grade 1-es hozaganyaggal történő összehegesztésével kapcsolatban, ahol a kötés minőségét, homogenitását mikro-CT-vel ellenőriztük, melyet a 7. fejezet tartalmaz. Ez tette számunkra szükségessé, hogy az új hegesztett szerkezetet is vizsgáljuk.

A szerkezeti vizsgálatokat próbatesteken végeztük, melyeket additív gyártással hoztunk létre Grade 23-as titánból. Összehasonlító szakítóvizsgálatot végeztünk oly módon, hogy próbatesteket vágtunk el, majd a geometriájukat megőrizve lézeres mikrohegesztéssel újra egyesítettünk.

Először egyszerü próbatesteket használtunk (6. ábra), melyek vizsgálata során azt tapasztaltuk, hogy a nyúlás mértéke befolyással bírhat a hegesztett kötés szilárdságára (7. ábra).

$\mathrm{Az}$ eredeti próbatest módosítására azért volt szükség, hogy a szakadási nyúlás mértékét csökkentsük.

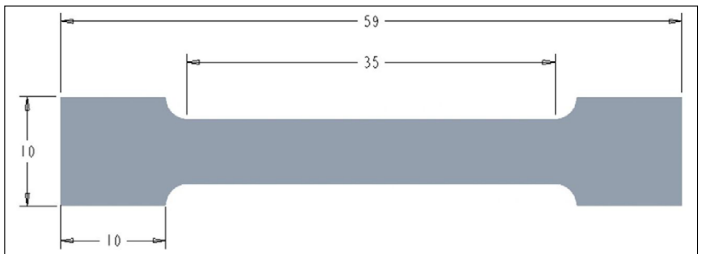

6. ábra. Az eredeti próbatest 
A módosított próbatesten bemetszést alkalmaztunk, olyan céllal, hogy a szakítóvizsgálat során biztosan a hegesztett kötés szakadjon, és így a hegesztett kötés szilárdsági tulajdonságait kapjuk meg, nem pedig a próbatestét (8. és 9. ábra).

Létrehoztuk az elvágott és hegesztett szerkezetű próbatesteket, valamint megismételtük az összehasonlító szakítóvizsgálatot (10., 11. és 12. ábra).

A szakítási eredmények, valamint a numerikus analízissel feltárt, a hálószerkezetben ébredő feszültségek összevetése alapján arra a következtetésre jutottunk, hogy a hegesztési varrat szilárd-

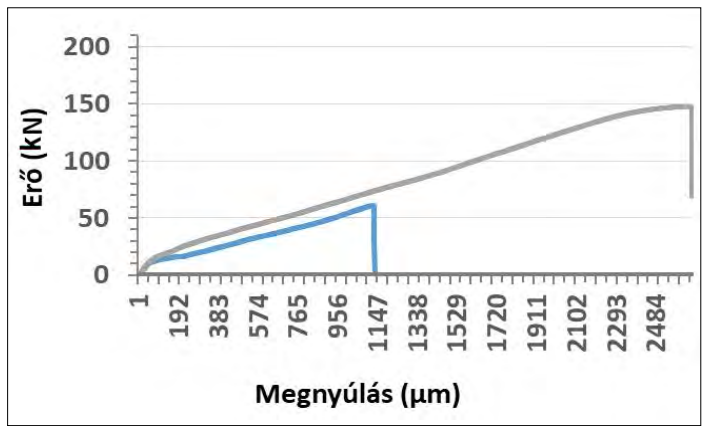

7. ábra. Az eredeti próbatestek szakítódiagramja. A szürke színü az alapanyag, a kék pedig a hegesztett próbatest

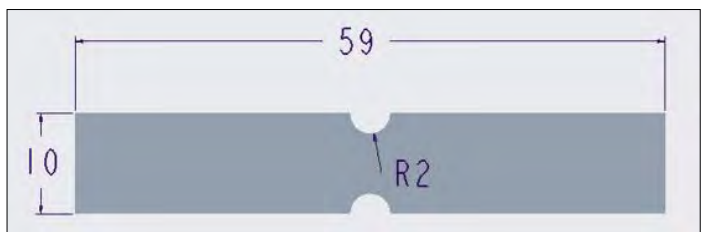

8. ábra. A módosított próbatest

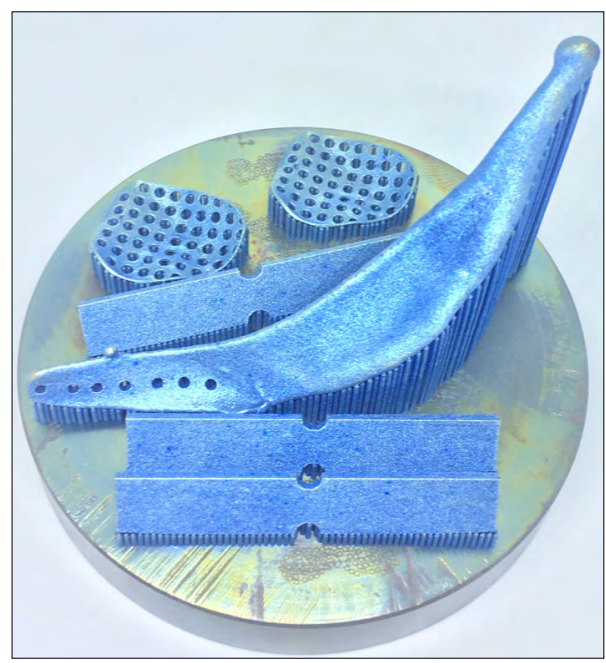

9. ábra. A próbatestek additív módon történő létrehozása sága megfelel az elvárt fizikai követelményeknek. A számításokból adódik, hogy a tengelyirányú átlagos terhelőerő (140 N átlagos terhelőerővel számolunk) húszszorosát elviseli a hegesztett szerkezet (13. ábra).

\section{Additív gyártással létrehozott bázis- lemez}

A gyártástechnológia fejlődése és a rendelkezésre álló géppark lehetővé tette számunkra a precíziós öntés kiváltását. Az így additív gyártással, azon belül Selective Laser Melting (SLM)

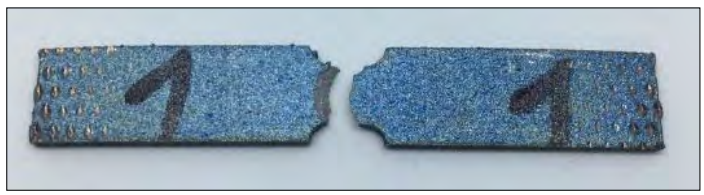

10. ábra. A módosított próbatest elszakítva

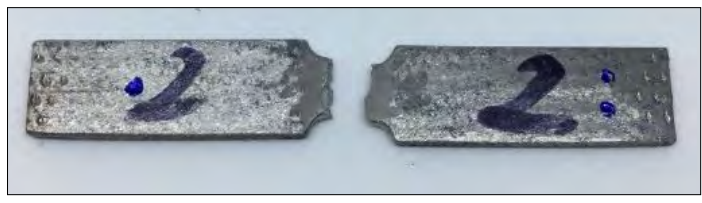

11. ábra. A hegesztett, módosított próbatest elszakítva

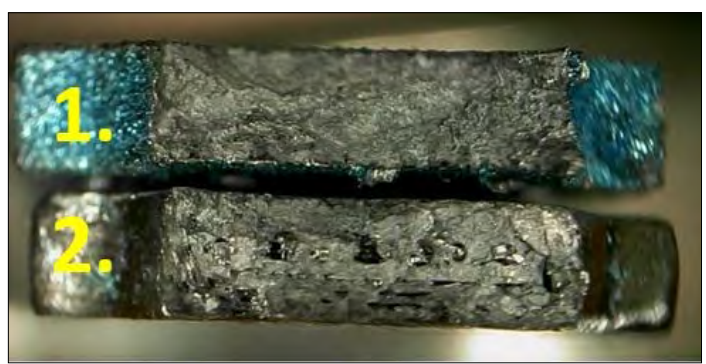

12. ábra. Az 1-es számú a módosított, a 2-es számú a módositott és hegesztett próbatest töretfelületének képe

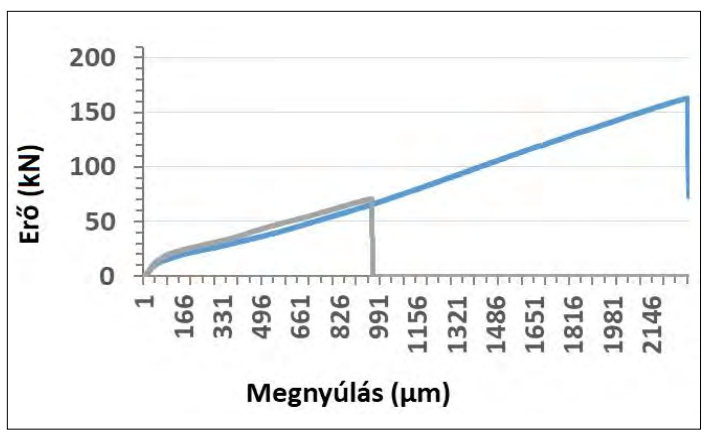

13. ábra. A módosított próbatestek szakítódiagramja. A kék színú az eredeti állapotú, a szürke pedig a hegesztett próbatest 
technológiával készült bázislemezeknél felmerült az egyetlen szerkezetben történő megvalósítás a rögzítési pontokkal együtt. A megmunkálás a gyártó által ajánlott hőkezelésű, nyomtatott fémszerkezetnél az alapanyag relatív ridegsége miatt rendkívül nehézkes lett (14. ábra). A hagyományos menetfúró szerszámok használata nem volt megoldható. Az implantátumok további illeszkedőfelületeinek precíziós utómunkálatai a befogás pontatlansága miatt nem volt kivitelezhető.

A vizsgálataink és tapasztalataink egyértelmü eredménye az lett, hogy a nyomtatott alaplemezt és a kétfázisú rögzítést biztosító menetes perselyeket lézersugaras hegesztéssel lehet a legpontosabban és leggazdaságosabban kivitelezni. Ez a tervezésnél virtuális elemek felhasználását tette szükségessé, amelyek a perselyek helyét pozicionáltan határozzák meg, valamint a hegesztéshez szükséges felületek kialakítását, élkiképzési szögeket és anyagvastagságokat tartalmazzák (15. ábra és 1. táblázat).
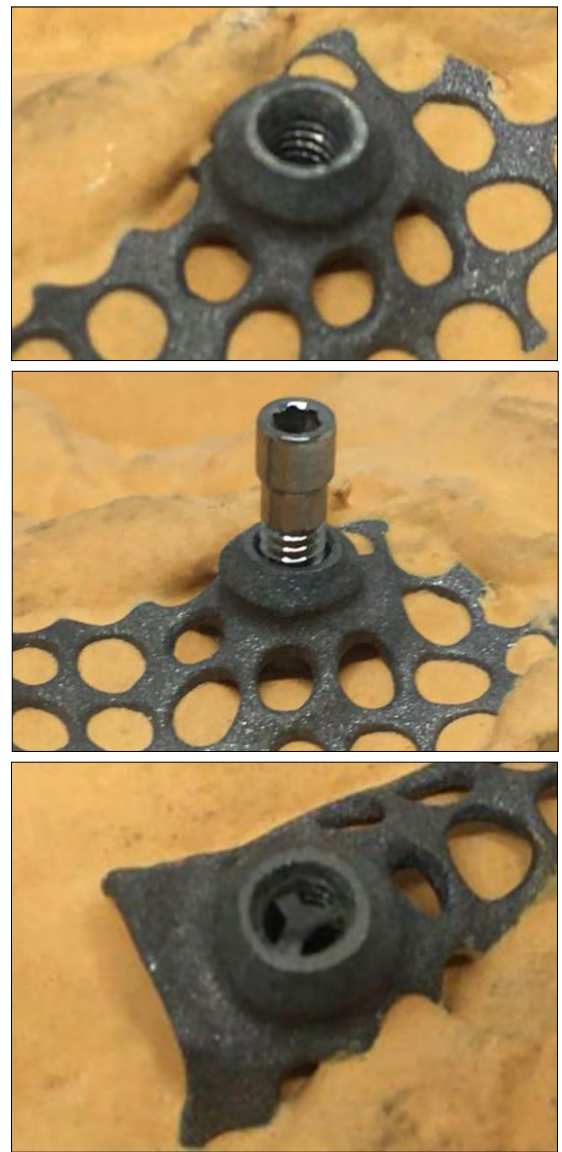

14. ábra. Példák az egyben nyomtatott fémszerkezetek megmunkálásának sikertelenségeire
A lemez nyomtatását követően 20 percig $600{ }^{\circ} \mathrm{C}$-on feszültségmentesítő hőkezelésre (légköri nyomáson, védőgáz nélkül) kerül sor, amit a 3-4 bar-os, $50 \mu$-os korundszemcsével történő felületi szemcseszórás követ. A manuális felületi átdolgozás után a virtuális tervezésnek megfelelően a hegesztendő elemek összeillesztése következik (16. ábra). Ezzel párhuzamosan a komplex parallelitást, tehát a rögzítőelemek párhuzamosságát is ellenőrizni kell. A CBCT-felvétel DICOM-fájlból generált csontfelszín 3D SLA fotopolimer anyagból 3D-nyomtatott modelljén történik a szerkezeti elemek összeállítása.

\section{A lézersugaras hegesztés}

$\mathrm{Az} \mathrm{impulzusos} \mathrm{üzemü} \mathrm{lézer} \mathrm{használatával} \mathrm{le-}$ hetőség nyílik a különlegesen nagy olvadáspontú anyagok hegesztésére. A hőbevitel gyors, az összehegesztendő felületek az olvadáspont fölé hevülnek, majd megszünik az impulzusciklus.

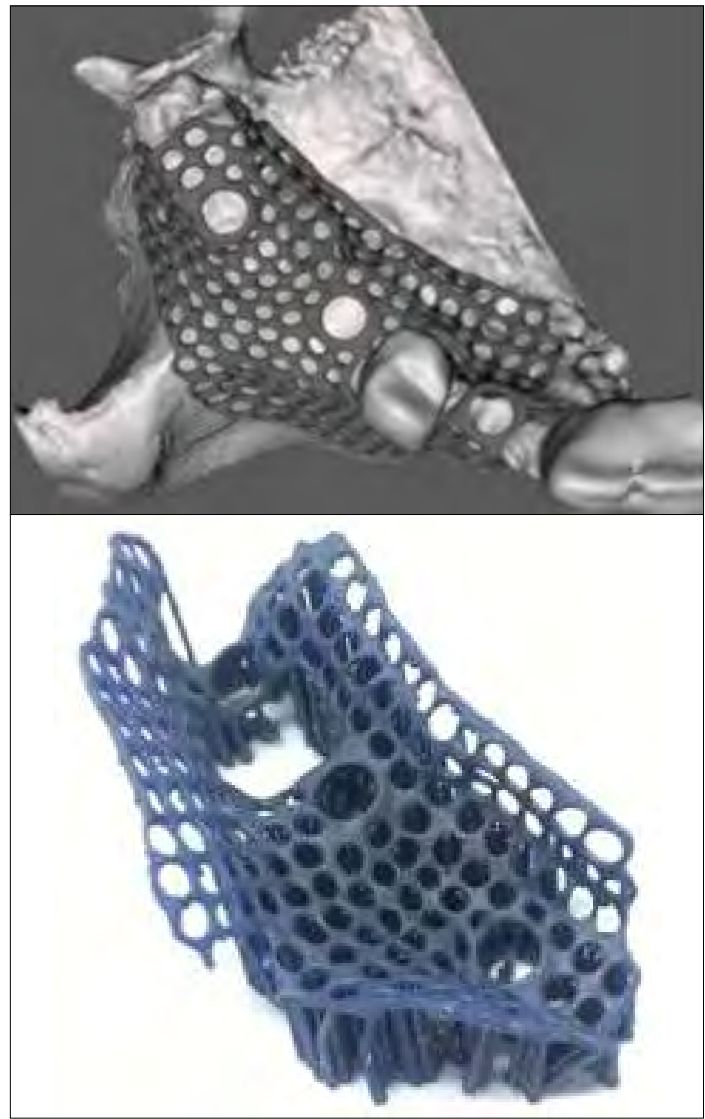

15. ábra. Az additív gyártással (3D nyomtatással) készült bázislemez testmodellje és a nyomtatott modell az alátámasztásokkal 
1. táblázat. Az additív gyártást végző lézerberendezés fö müszaki jellemzői

\begin{tabular}{|l|l|}
\hline \multicolumn{1}{|c|}{ Technikai adatok } & \multicolumn{1}{c|}{ SISMA mysint100 } \\
\hline Munkatér térfogata & dia. $100 \times 100 \mathrm{~mm}$ \\
\hline Lézerforrás & $200 \mathrm{~W}$ \\
\hline $\begin{array}{l}\text { Fókuszálható lézersugár- } \\
\text { átmérő }\end{array}$ & $50 \mu \mathrm{m}$ \\
\hline Tipikus rétegvastagság & $20-40 \mu \mathrm{m}$, változtatható \\
\hline Energiaforrás & $220-240 \mathrm{~V}-50-60 \mathrm{~Hz}$ \\
\hline $\begin{array}{l}\text { Maximális abszorbeált } \\
\text { teljesítmény }\end{array}$ & $1,53 \mathrm{~kW}$ \\
\hline Inert védőgáz & nitrogén, argon \\
\hline Inertgáz-ellátás & $6 \mathrm{~mm} / 2,5-5 \mathrm{bar} 35 \mathrm{l} / \mathrm{min}-$ nél \\
\hline Inertgáz-fogyasztás & $<0,3 \mathrm{l} / \mathrm{min} 0,5 \% \mathrm{O}_{2}$-nél \\
\hline O -koncentráció & $0,3 \%$ \\
\hline Berendezés méretei & $1390 \times 777 \times 1600 \mathrm{~mm}$ \\
\hline Berendezés tömege & $650 \mathrm{~kg}$ \\
\hline
\end{tabular}
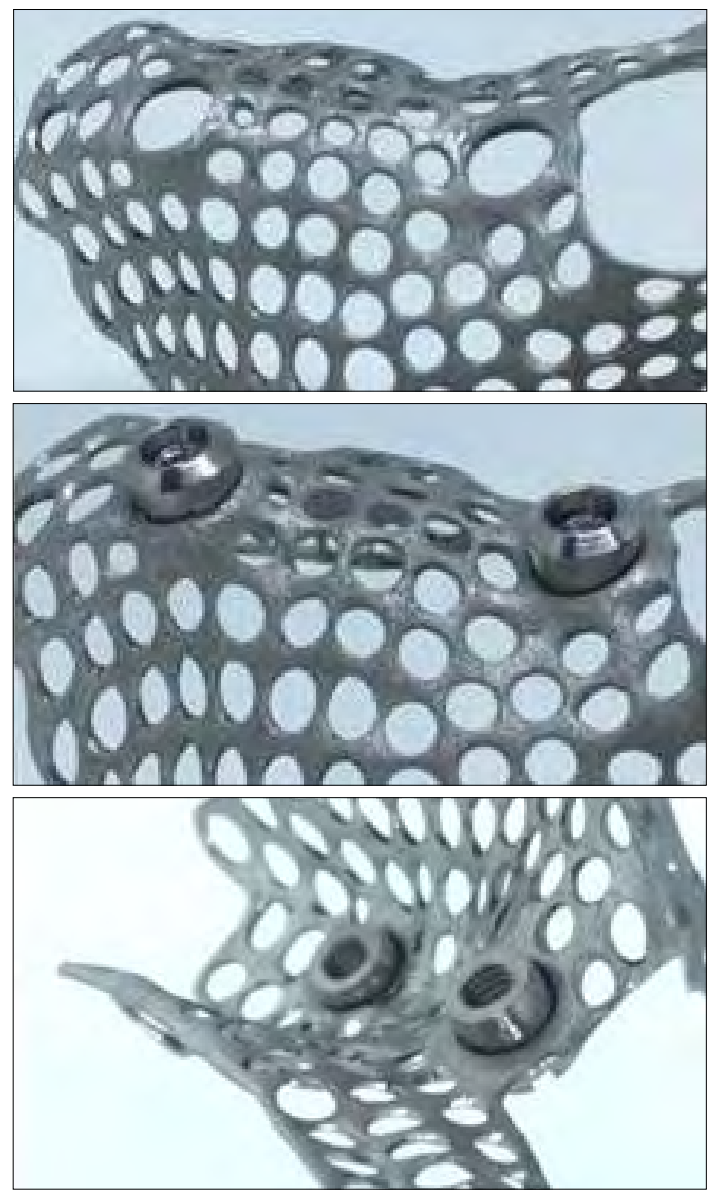

16. ábra. A szerkezeti elemek összeállítása a hegesztéshez a perselyelemek illesztésével
Ennek ismétlődésével, valamint a sugárnyaláb mozgatásával kialakul az összeolvadt varrat. Ez a hegesztési eljárás az alapja a lézersugaras mikrohegesztésnek.

Ily módon van lehetőségünk a titán és ötvözeteinek mély beolvadású varrattal történő összehegesztésére.

Az összeállítandó elemek a nyomtatott alaplemezből (Ti Grade 23, Ti-6Al-4V), hozaganyagból (Ti Grade 1, Ø 0,2 mm huzal) és a pillérek menetes perselyeiből (Ti Grade 5, hengerelt, húzott előgyártmányból esztergálva) tevődnek össze.

A lézeres hegesztés rögzítő ponthegesztéssel kezdődik a deformációk elkerülése végett, argon védőgáz alatt.

$\mathrm{Az}$ általunk használt keresztmetszetű darabok egyesítése, az illesztési hézag körszimmetrikus, mélyvarratos hegesztése után (lézeres hegesztőgép impulzuslézer beállításának paraméterei: 260-280 V, 5-8,5 ms, 5,0 Hz, fókusz: 0-tól 2-ig) hozaganyaggal (ötvözetlen titán, Grade 1) a varrat feltöltésre kerül a lézeres hegesztőgép beállított technológiai változói alapján (lézeres hegesztőgép impulzuslézer beállításának paraméterei: 300-320 V / 8,5 ms, 5,0 Hz, fókusz 1-től 4-ig) (17. ábra).

A felrakott felületek simításánál alkalmazott lézeres hegesztőgép impulzuslézer-paraméterei: 260-290 V, 8,5 ms, 5,0 Hz, fókusz 3-tól 10-ig. A beesési szög és a lézerfolt átmérőjének növelésével elsimítjuk a hegesztési varrat felületét (2. táblázat). Az utolsó hegesztési fázis a menetes persely fenéklemezének elhelyezése. A kötőhegesztés után az egyesített szerkezeteket ismételt hőkezeléssel feszültségmentesítjük.

$\mathrm{Az}$ implantátum lemezszerkezetének utókezelése a hegesztés után a varratok tisztításával, redőzöttségének kézi elsimításával, összetett élgeometriájú csiszolóeszközökkel történik. A digitális technikával történt tervezés és gyártás ellenére jelentős manuális munkát igényel még a befejező fázis, amely a dorzális felület mikroszemcsés szemcseszórása (50 $\mu$, 1,5 bar) után az érdességi mikrobarázdák megszüntetésére szolgáló savas pácolással és a buccalis felület tükrösre polírozásával ér véget (18. ábra). 

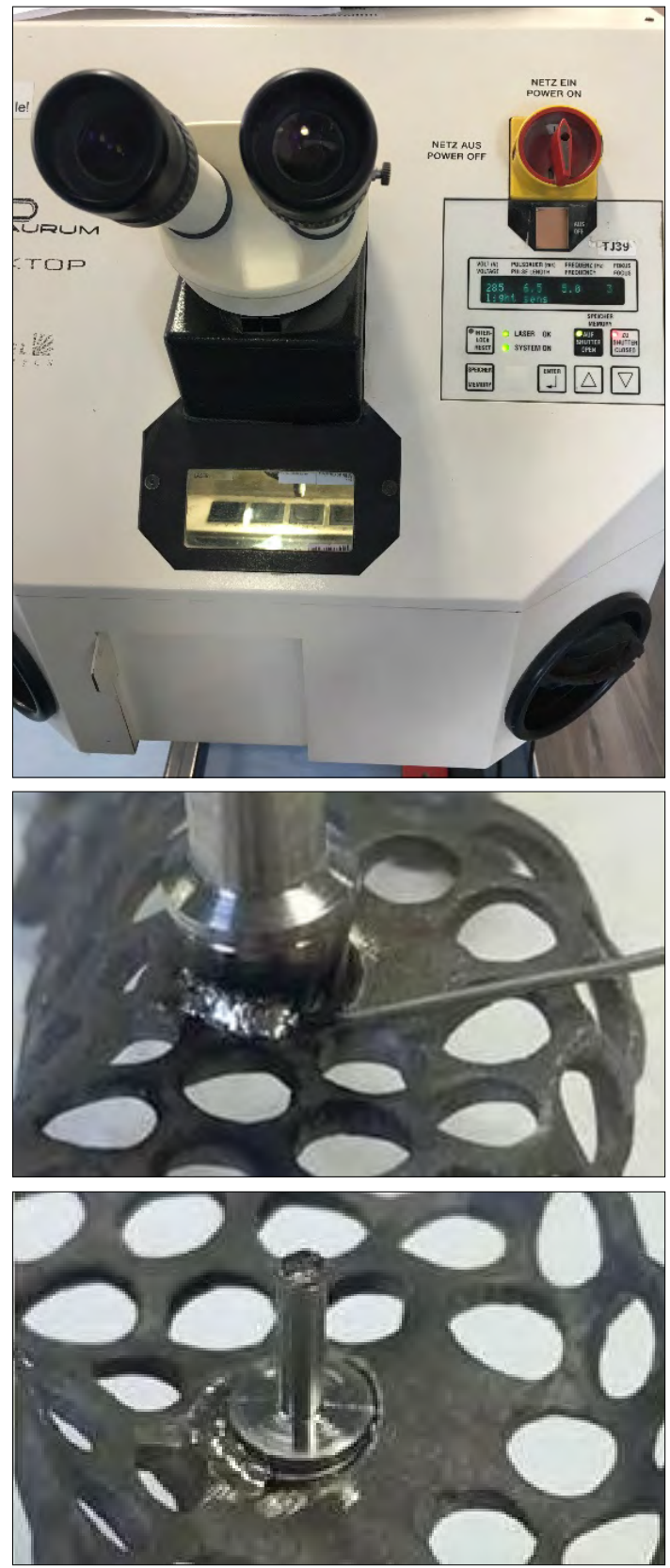

17. ábra. A lézersugaras hegesztés berendezésének kezelöfelülete és a hegesztés fázisai

A felszín előkészítése fontos az implantátumszerkezet csont-, illetve nyálkahártya-érintkezésénél, mivel befolyásolja a csontintegráció gyorsaságát, ami növeli a stabilitást. Befejezésül ellenőrző vizsgálatokat végzünk minden egyedi implantátumon röntgen mikro-CT segítségével.
2. táblázat. Az általunk alkalmazott Dentaurum Basel Laser Desktop mikrohegesztő berendezés fö müszaki jellemzői

\begin{tabular}{|l|l|}
\hline \multicolumn{2}{|c|}{ Lézer hegesztőgép paraméterei } \\
\hline Lézerkristály & $\mathrm{Nd}$ YAG \\
\hline Hullámhossz & $1064 \mathrm{~nm}$ \\
\hline Max. átlagteljesítmény & $50 \mathrm{~W}$ \\
\hline Impulzusenergia & $50 \mathrm{~J}$ \\
\hline $\begin{array}{l}\text { Impulzus-csúcsteljesít- } \\
\text { mény }\end{array}$ & $5 \mathrm{~kW}$ \\
\hline Impulzus-időtartam & $0,5-20 \mathrm{~ms}$ \\
\hline Impulzusfrekvencia & $25 \mathrm{~Hz}$ \\
\hline Impulzusformátum & $\begin{array}{l}4 \text { előre kialakított impulzus- } \\
\text { forma }\end{array}$ \\
\hline Lézerhűtés & $\begin{array}{l}\text { integrált víz-levegő-hő } \\
\text { cserélő }\end{array}$ \\
\hline Elektromos kapcsolás & $200-240 \mathrm{~V} / 50-60 \mathrm{~Hz} / 10 \mathrm{~A}$ \\
\hline Max. energiafogyasztás & $2,2 \mathrm{~kW}$ \\
\hline
\end{tabular}
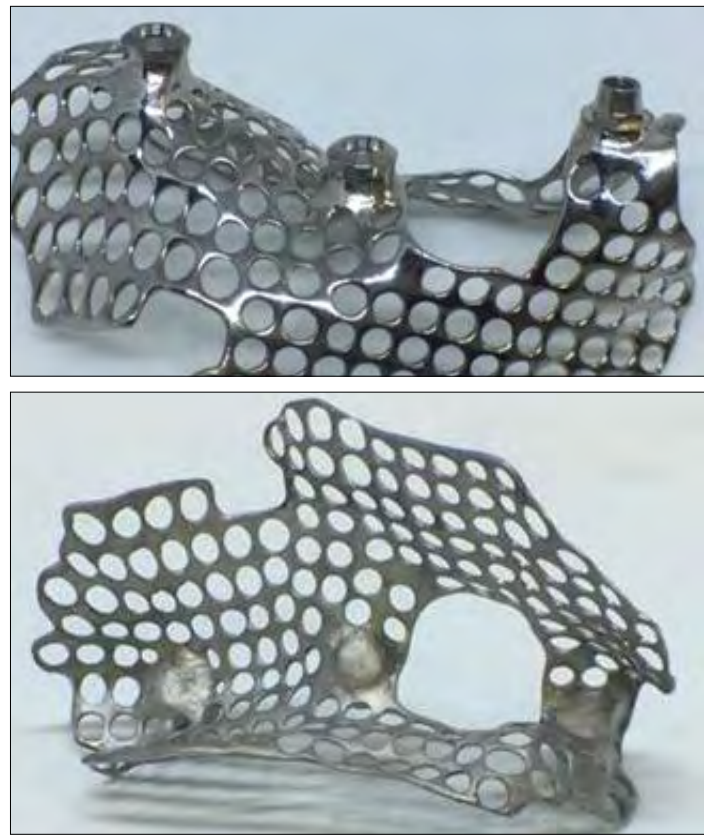

18. ábra. A subperiostealis implantátum egyesített szerkezete felületkezelve

\section{Roncsolásmentes anyagvizsgálat mikro-CT-vel}

A vizsgálat során lehetőségünk nyílik a hegesztési varrat homogenitási hiányosságainak felderítésére, amelynek mértéke befolyással bír a hegesztett kötés szilárdságára, minőségére és tartósságára (19. ábra). 
A hegesztett varrat szilárdságát vizsgáló próbatesteken végzett elemzések alapján minőségi standardokat határoztunk meg. Az összegzett elemek hegesztett térfogatának a mikro-CT-vel kimutatható 90\%-os homogenitással kell rendelkezniük, és a legnagyobb zárvány mérete nem haladhatja meg a $0,05 \mathrm{~mm}^{3}$-t, valamint a felülettől mért távolsága 0,3 mm-nél nagyobb kell hogy legyen.

\section{Próbadarabon készített hegesztési varrat metszetének vizsgálata}

A hegesztési varrat minőségének elemzéséhez az eredetivel azonos alapanyagokból és technológiával egy próbaimplantátumot készítettünk, melynek metszetét maratás után mikroszkóppal vizsgáltuk (Nikon TS100 mikroszkóppal) (20. ábra).

A lézeres mikrohegesztésnél nem következik be jelentős szemcsedurvulás, és keskeny hőhatásövezet alakul ki. Az ily módon készített hegesztési varrat több szempontból is kedvező, a varratszerkezet homogén, és a varratok hőhatásövezete

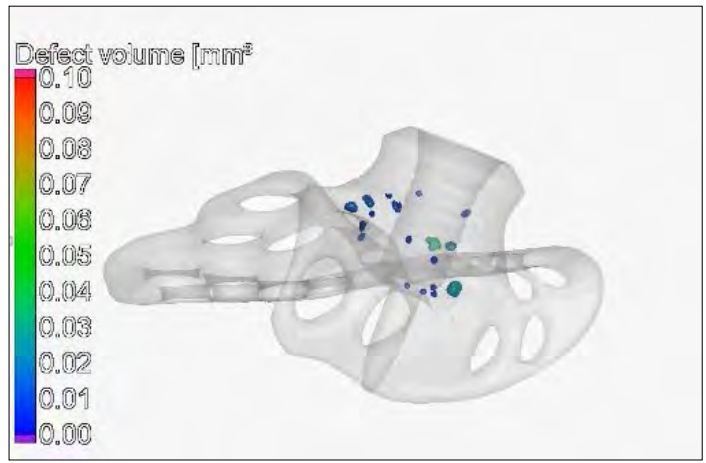

19. ábra. Geometriai sajátosságokat tartalmazó mintadarab hegesztési varratának mikro-CTvizsgálata

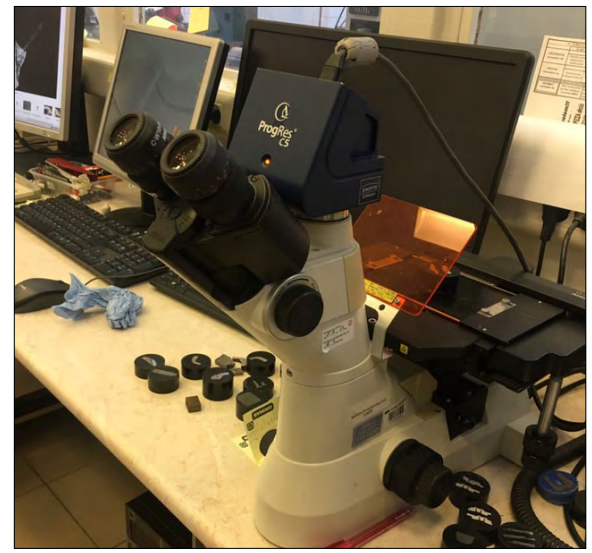

20. ábra. A csiszolatvizsgálathoz használt mikroszkóp egyenletes és folytonos (21. ábra).

A metszetet, illetve a csiszolatot úgy alakítottuk ki, hogy a mikro-CT-felvétel alapján fellelhető, legnagyobb hegesztési gázzárványok is láthatóvá váljanak a 22. ábra jelölt helyein.

\section{0. Összefoglalás}

A végleges csavarokkal rögzített fogmű elkészítése a szájba beültetett implantátum fölött lévő nyálkahártya teljes gyógyulása, valamint a titánhálót körülvevő csontszövet osszeointegrációja után valósul meg (23. és 24. ábra).

Az általunk újragondolt és gyártástechnológiájában fejlesztett, kétfázisú rögzítési pontokat tartalmazó, subperiostealis implantátum mind anyagában, mind a kialakítás komplex technológiájában újszerüséget képvisel. Az osztható, két fázisban kialakított rögzítési pontok lehetőséget
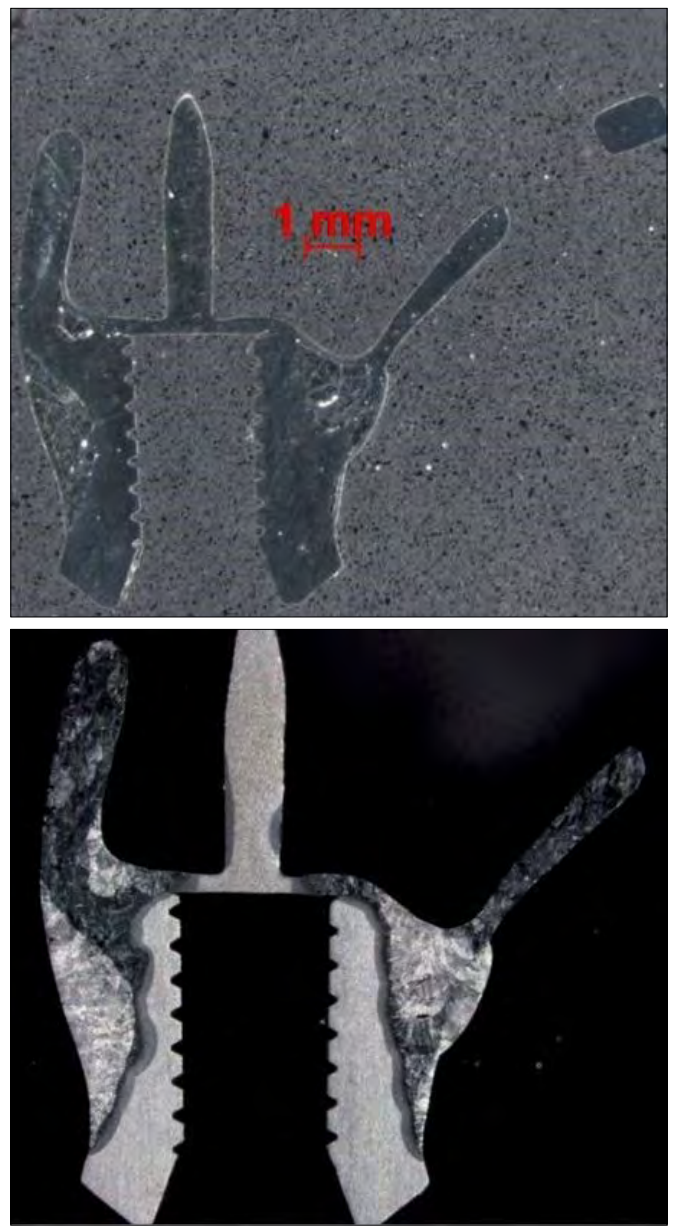

21. ábra. A hegesztett titánszerkezet metszeti képei (optikai mikroszkóppal különbözö megvilágítással, kontrasztokkal készített képek) 

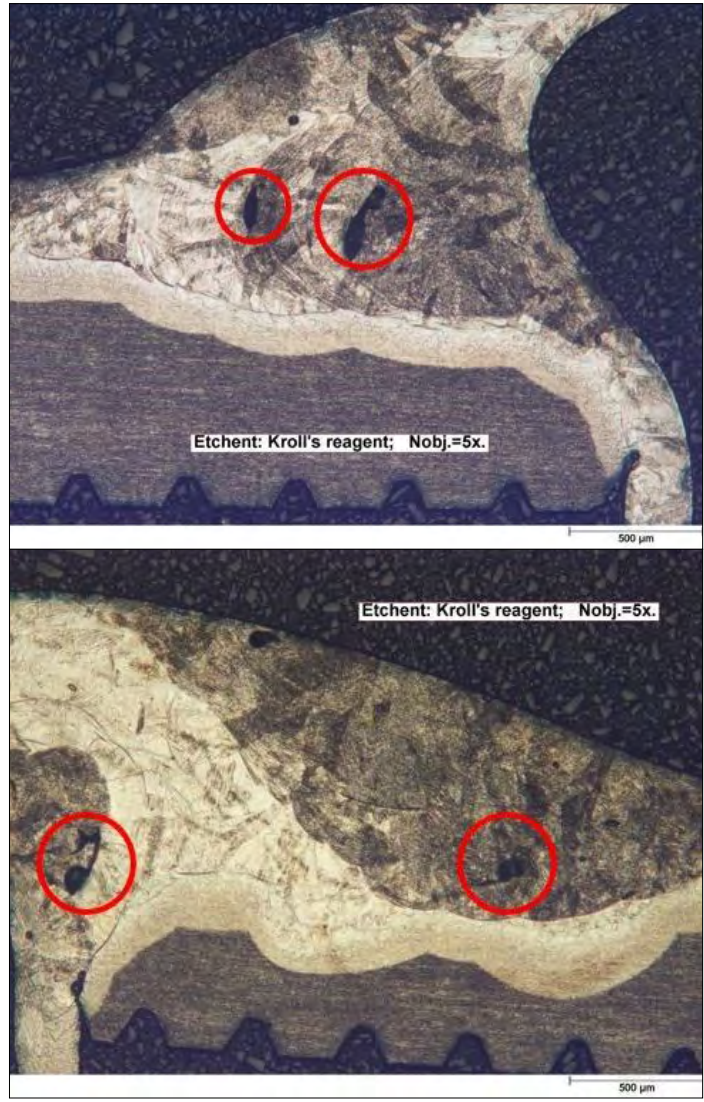

22. ábra. A hegesztett titánszerkezet metszeti képei a gázzárványok jelölésével

adnak a zárt seb alatti izolált gyógyulásra. A hegesztett perselyek magasságának minimalizálása a műtéti sebzárásnál, illetve a gyógyulást követően a szubgingivális nyálkahártya felületi irritációját csökkenti. Azon páciensek számára nyújt segítséget, akiknek nem áll rendelkezésre kellő csontvolumenük a fogaik elvesztése, valamint a csontállományok leépülése után a hagyományos, körszimmetrikus implantátumok beültetésére.

\section{Köszönetnyilvánítás}

Köszönettel tartozunk a „Nemzetköziesítés, oktatói, kutatói és hallgatói utánpótlás megteremtése, a tudás és technológiai transzfer fejlesztése, mint az intelligens szakosodás eszközei a Széchenyi István Egyetemen” c. pályázat támogatásáért.

\section{Szakirodalmi hivatkozások}

[1] Malinov S., Sha W.: Application of artifical neural networks for modeling correlations in titanium alloy. Materials Science and Engineering A, 41/1-2. (2010) 140-146. https://doi.org/10.1016/j.msea.2003.09.029
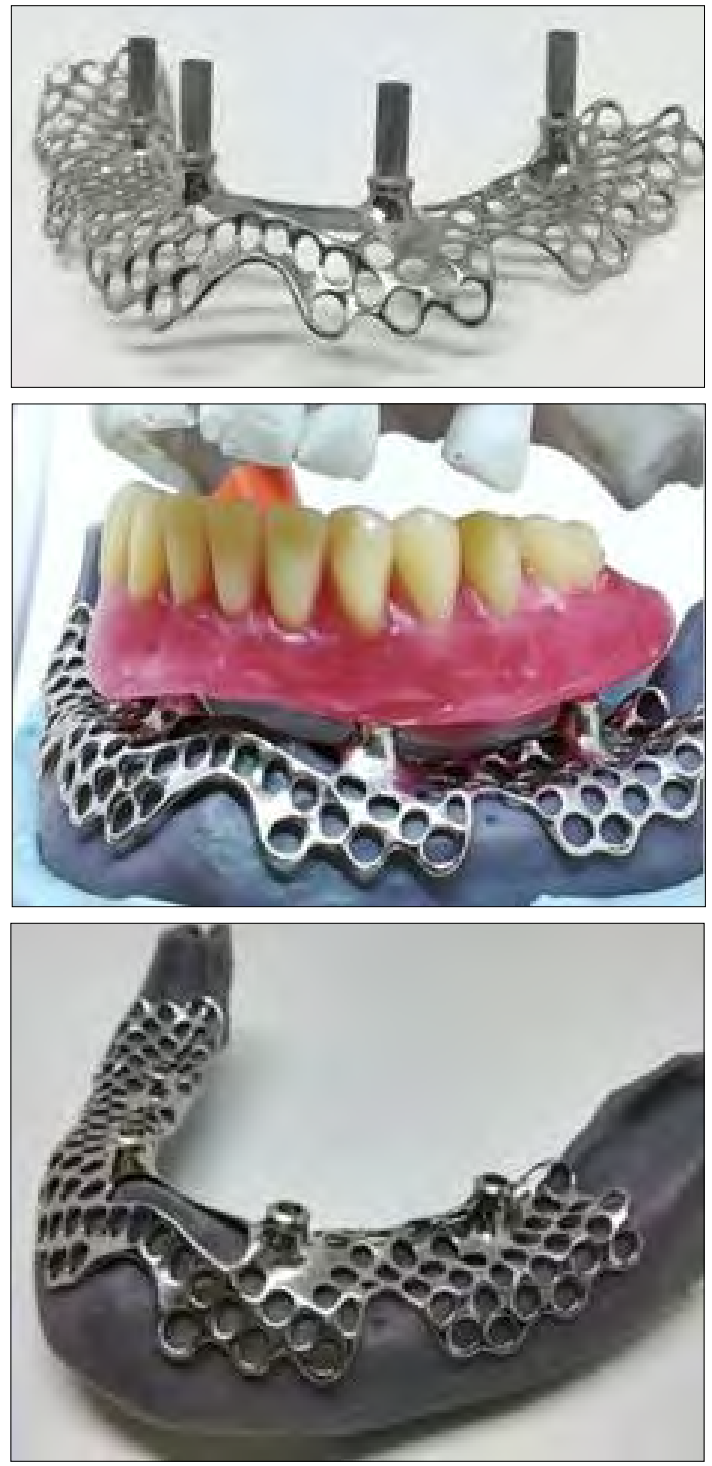

23. ábra. A kész, sterilizálás előtti implantátumlemezek a fogmü modelljével

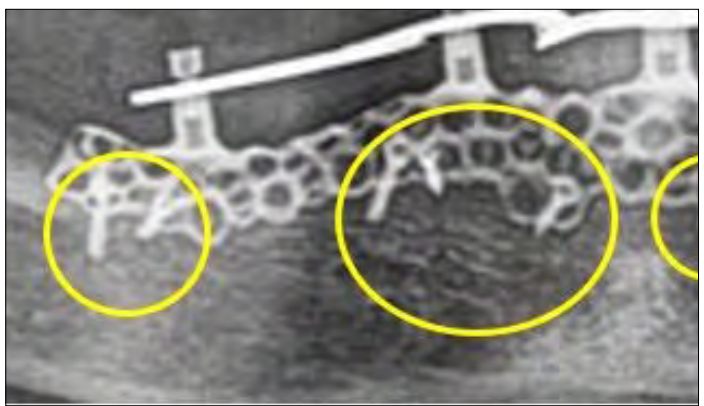

24. ábra. A beültetett egyéni, subperiostealis implantátum röntgenképe a rögzítő mikrocsavarokkal 
[2] Shrivastava S.: Medical Device Materials, Anaheim $C A$. In: Proceedings of the Materials and Processes for Medical Devices Conference, 2003. 417. https://www.asminternational.org/documents/10192/1849770/06974g_frontmatter.pdf

[3] Xie J., Safarevich S.: Laser materials porcessing for medical devices. In: Shrivastava S. (ed.): Proceedings of the Materials and Processes for Medical Devices Conference, Anaheim, CA, ASM International. 2003. 25-30.

[4] Saresh N., Gopalakrishna Pillai M., Mathew J.: Investigations into the effects of electron beam welding on thick Ti-6Al-4V titanium alloy. Journal of Materials Technology, 192-193. (2007) 83-88. https://doi.org/10.1016/j.jmatprotec.2007.04.048

[5] Welding Handbook. Weldings Processes. vol. 2., American Welding Society, Miami, FL, 1988. 695697.

[6] Welding Handbook. Metals and Their Weldability, vol. 4., American Welding Society, Miami, FL, 1982. 447-449.

[7] Gupta B., Krishna V. G.: Aerospace Materials, vol. 1., S-Chand and Company Ltd., New Delhi, India, 1996.

[8] Kelly S. M, Kapmpe S. L.: Microstructural evolution in laser-deposited multilayer Ti-6Al-4V builds.PartII.Thermalmodeling.Metallurgicaland Materials Transactions, A 35/6. (2004) 1869-1879. https://doi.org/10.1007/s11661-004-0095-7

[9] Qian L., Mei K., Liang J., Wu X.: Influence of position and laser power on thermal history and microstructure of direct laser fabricated Ti-6Al-4V samples. Materials Science and Technology, 21/5. (2005) 597-605. https://doi.org/10.1179/174328405X21003

[10] Dinda G. p., Song L., Mazumder J.: Fabrication of Ti-6Al-4V scaffolds by direct metal deposition. Metallurgical and Material Transactions A - Physical Metallurgy and Materials Science, 39/12. (2008) 2914-2922.

https://doi:10.1007/s11661-008-9634-y

[11] Nowotny S., Scharek S., Beyer E., Richter K. H.: Laser beam build-up welding: precision in repair, surface cladding, and direct $3 D$ metal deposition. Journal of Thermal Spray Technology, 16/3. (2007) 344-348. https://doi:10.1007/s11666-007-9028-5

[12] Taminger K. M., Hafley R. A.: Electron beam freeform fabrication for cost effective nearnet shape manufacturing. In: NATO/RTO AVT-139 specialists meeting on cost effec- tive manufacture via net shape processing, Amsterdam (The Netherlands): NATO, (2006) https://ntrs.nasa.gov/archive/nasa/casi.ntrs.nasa. gov/20080013538.pdf

[13] Katou M., Oh J., Miyamoto Y., Matsuura K., Koduh M.: Freeform fabrication of titanium metal and intermetallic alloys by three-dimensional micro welding. Materials and Design, 28/7. (2008) 2093-2098. https://doi.org/10.1016/j.matdes.2006.05.024

[14] Clark D., Bache M., Whittaker M.: Shaped metal deposition of a nickel alloy for aero engine applications. Journal of Materials Processing Technology, 203/1-3. (2008) 439-448. https://doi.org/10.1016/j.jmatprotec.2007.10.051

[15] Baufeld B., Van der Biest O., Gault R.: Additive manufacturing of Ti-6Al-4V components by shaped metal deposition: Microstructure and mechanical properties. Materials and Design, 31/1. (2010) 106-111. https://doi.org/10.1016/j.matdes.2009.11.032

[16] Barreda J. L., Santamaram F., Azpiroz X., Irisarri A. M., Varona J. M.: Electron beam welded high thickness Ti-6Al-4V plates using filler metal of similar and different composition to the base plate. Vacuum 62/2-3. (2001) 143-150. https://doi.org/10.1016/S0042-207X(00)00454-1

[17] Baeslack W. A., Becker D. W., Froes F. H.: Advances in titanium alloy welding metallurgy. Journal of Metals, 36/5. (1984) 46-82. https://slideheaven.com/queue/advances-in-titanium-alloy-welding-metallurgy.html

[18] Balasubramanian M., Jayabalan V., Balasubramanian V.: Developing mathematical models to predict tensile properties of pulsed current gas tungsten arc welded Ti-6Al-4V alloy. Materials and Design, 29/1. (2008) 92-97. https://doi.org/10.1016/j.matdes.2006.12.001

[19] Li X., Xie J., Zhou Y.: Effects of oxygen contamination in the argon shielding gas in laser welding of commercially pure titanium thin sheet. Journal of Materials Science, 40/13. (2005) 3437-3443. http://www.camj.uwaterloo.ca/pdf/Zhou/JMS2005\%20Li.pdf

[20] Brandl E., Baufeld B., Leyens C., Gault R.: Additive manufactured Ti-6Al-4V using welding wire: comparison of laser and arc beam deposition and evaluation with respect to aerospace material specifications. ScienceDirect - Physics Prodedia, 5/1. (2010) 595-606. https://doi.org/10.1016/j.phpro.2010.08.087 